\title{
Investigating the influence of culture on language patterns: a contrastive corpus-based study
}

\section{Investigando a influência da cultura nos padrões da linguagem: um estudo contrastivo baseado em corpus}

Sandra Navarro*

\footnotetext{
* PhD in Translation Studies from University of São Paulo (FFLCH-USP). 
Abstract: This paper aims to explore the intrinsic relationship between language and culture. It attempts to shed light on the underlying cultural associations embedded in collocational meaning across languages. The notion of culture adopted in this study is related to how individuals perceive the world and interpret reality around them. This paper brings together the principles of Corpus Linguistics and Intercultural Studies to investigate a corpus of travelers' reviews (English/Portuguese) and interpret results within the framework of the model of cultural orientations in WALKER et al. (2003). In a study of collocations with the word staff and their equivalents in Portuguese, we demonstrate how a language pattern can also represent a cultural pattern, thus showing that cultural orientations play a role in the identification of collocational meaning across languages.

Keywords: Corpus Linguistics; Intercultural studies; cultural orientations; collocations; Travelers' reviews.

Resumo: Este estudo aborda a intrínseca relação entre linguagem e cultura, mais especificamente, busca lançar luz sobre as associações culturais implícitas no significado colocacional. A noção de cultura em observação neste trabalho está relacionada a como os indivíduos percebem o mundo e interpretam a realidade. Esta pesquisa combina os princípios da Linguística de Corpus e dos Estudos Interculturais ao investigar um corpus de resenhas de viajantes (inglês/português) e interpretar os resultados com base no modelo de orientações culturais proposto em Walker et al. (2003). A partir da análise de colocações com a palavra staff e seus equivalentes em português, demonstramos como um padrão lexical também pode representar um padrão cultural, o que aponta para a importância das orientações culturais na identificação do significado colocacional.

Palavras-chave: Linguística de Corpus; Estudos Interculturais; orientações culturais; colocações; resenhas de viajantes.

TradTerm, São Paulo, v.37, n. 2, janeiro/2021, p. 644-670

Número Especial - Linguística de Corpus

www.revistas.usp.br/tradterm 


\section{Introduction: language-culture relationship and corpus studies}

Language and culture are intrinsically related. In fact, language has been referred to as the heart within the body of culture (BASSNET 1980: 14), as the cultural lens through which people perceive the world (SAPIR 1949: 162) or as the vehicle by which the facts of culture are shaped and communicated (GLADSTONE 1969: 114). The vital connection between language, culture, thought and behavior was initially made by anthropologists and ethnolinguistics.

Wilhelm von Humboldt (1767-1835) considered language as an "expression of both the culture and the individuality of the speaker, who perceives the world through language" (SNELL-HORNBY 1995: 40). Years later Edward Sapir and Benjamin Lee Whorf advanced the idea that language influenced our perceptions of the world by maintaining that "no two languages are ever sufficiently similar to be considered as representing the same reality. The worlds in which different societies live are distinct worlds, not merely the same world with different labels" (SAPIR 1949: 162). This became known as the Sapir-Whorf hypothesis of language relativity and was based on the study of exotic languages, such as Hopi spoken by American Indians, whose verb system directly affected the speakers' conception of time (WHORF 1973: 57-64). Despite the controversies, these studies put forward the argument that language could only be interpreted within a culture. Also convinced of this idea was another anthropologist, Bronislaw Malinowski, who noted the importance of the context of situation and context of culture to the identification of meaning in language: "language is essentially rooted in the reality of culture (...), it cannot be explained without constant reference to these broader contexts of verbal utterance" (MALINOWSKI 1938: 305).

MALINOWSKI's theories influenced the works of linguists such as Firth (1957) and Halliday (1985) who advocated the centrality of attested or real language use for linguistic analysis. FIRTH argues that the meaning of a word is not fixed and independent but it is strictly correlated with the co-text and

\footnotetext{
TradTerm, São Paulo, v.37, n. 2, janeiro/2021, p. 644-670 Número Especial - Linguística de Corpus www.revistas.usp.br/tradterm
} 
context in which it occurs. Hence the focus of interest shifts from single words in fragmented texts to the meaningful relations words enter into with the other words around them, making up "units of meaning", observed in whole attested texts (SINCLAIR 1996). Within this framework, the impact of massive corpus evidence has been revolutionary, as it represents authentic language use within the broader contexts of culture and situation.

Despite the proven potential for joint collaboration between Corpus Linguistics (CL) and Intercultural Studies (IS) (NAVARRo 2018, BIANCHI 2012, MANCA 2012, MUNTZ 2001, SCHMid 2003), there has been a limited number of cultural studies that systematically apply corpora and quantitative analytical methods (BIANCHI 2012: 28). In this regard, Navarro (2018) demonstrated empirically how a deeper understanding of both cultural and linguistic conventions plays a key role in functionalist approaches to tourism translation.

By drawing on the results from this extensive research (NAVARRO 2018), this paper aims to demonstrate how a corpus study of language patterns can tell us not only about language preference and real language use, but can reveal those underlying meanings influenced by culture. In other words, our ultimate goal is to shed light on the cultural associations embedded in language patterns, thus showing that culture plays a significant role in the identification of collocational meaning across languages. To that aim, we present a contrastive analysis of collocations extracted from a corpus of TripAdvisor travelers' reviews written in English by Americans and in Portuguese by Brazilians and interpret these findings within the theoretical frame of cultural orientations (WALKER et al. 2003, HALL 1977, HOFSTEDE 2001, TROMPENAARS \& HAMPDEN-TURNER 2012). First this paper provides an overview of some relevant theoretical concepts on culture and models of cultural orientations, which is followed by a description of the study corpus and methods. It will then go on to describe a quantitative and qualitative analysis of a specific case of collocation regarding hotel service evaluation. The discussion section draws together the main findings and establishes their relationship to cultural orientations. We conclude this paper with some final remarks on the potential contributions of our findings.

TradTerm, São Paulo, v.37, n. 2, janeiro/2021, p. 644-670 Número Especial - Linguística de Corpus www.revistas.usp.br/tradterm 


\section{Theoretical framework: culture and cultural orientations}

Culture is a complex and multi-faceted phenomenon that can be observed from numerous different perspectives. As anticipated above, the notion of culture adopted in this study is related to how individuals perceive the world and interpret reality around them. This is culture considered from a broader anthropological sense to refer to all socially conditioned aspects of human life (HYMES 1964; SNELL-HORNBY 1995: 40). This concept of culture has been defined by Göhring (1977: 10) as follows:

(...) Everything one needs to know, master and feel in order to judge where people's behavior conforms to or deviates from what is expected from them in their social roles and in order to make one's own behavior conform to the expectations of the society concerned

(...) (GÖHRING 1977: 10 apud SNELL-HORNBY 1988: 40)

In this sense, culture involves a complex set of habits acquired by members of a given group, making up explicit and implicit patterns of behavior, and is consequently associated with our sense of "normal". This means that we are dealing with culture as an internalized and shared system for interpreting reality and experience, as Katan (2004: 20) puts it:

The culture under discussion here is not visible as a product, but is internal, collective and is acquired rather than learned. Acquisition is the natural, unconscious learning of language, behavior, values and beliefs through informal watching and hearing.

The definition above focuses on the implicit and unconscious aspects of culture. This presupposes the existence of models which describe culture as operating on different levels, on an objective to subjective continuum (HALL [1959] 1990; TROMPENAARS AND HAMPden TURNER 2000; HOFSTEDE 2001; KLUCKHOHN 1961). The core idea behind these models is that culture is made up of visible and concrete manifestations, such as art, music, food, architecture, customs, traditions, language; as well as invisible or out-of-awareness aspects, which are linked to a world of values, ideas and meanings shared by a group (WALKER et al. 2003: 39-40; KATAN 2004: 44-46). This subjective level comprises our

TradTerm, São Paulo, v.37, n. 2, janeiro/2021, p. 644-670 Número Especial - Linguística de Corpus www.revistas.usp.br/tradterm 
"deep dispositions, values and norms that guide our behavior, provide our perspectives of the world, and profoundly define our sense of self and group affiliations" (WALKER et al. 2003: 41). In other words, this is the level of cultural orientations and the focus of our discussions.

Kluckhohn and Strodtbeck (1961: 341) define cultural orientations as "a generalized and organized principle concerning basic human problems, which pervasively and profoundly influences man's behavior." These basic human problems refer to universal or fundamental issues of existence for which each society develops its own set of solutions. Roughly these dilemmas revolve around the relationships between people and nature, people and time, people and society (TrompenAARS AND HAMPDEN-TURNer 2012: 11). Responses to such issues gradually become consistent and standardized choices to the point that they escape one's awareness and become tacit assumptions or patterns that orient the thoughts and actions of a given group (TROMPENAARS AND HAMPDENTURNER 2012: 31; WALKER et al. 42-43). The full range of possible answers to these human dilemmas is found in each society but a dominant solution, or orientation, is usually present (STEWART AND BENNET 1991: 12). Every culture distinguishes itself from others by its dominant orientations, which represent generalizable cultural variables that allow for cross-cultural investigations.

A number of authors have put forward various taxonomies for cultural orientations (see NAVARRO 2018: 64). The model chosen for our analysis was proposed by Danielle Walker, Thomas Walker and Jorg Schmitz (2003) and is in fact an amalgamation of the main contributions by different authors (HALL [1959] 1990, 1977, 1989, HOFSTEDe 2001; KLUCKHOHN AND STRODTBECK 1961; TrompenaARs and Hampden-TuRner 2012; SteWart and Bennet 1991, Rhinesmith 1971). The model consists of ten dimensions, each comprises one or more orientations: communication, space, power, individualism, competitiveness, structure, thinking and environment. Due to limited space, we shall describe in the discussion section only the orientations applied to the interpretation of our data (WALKER et al. 2003: 56-85; TROMPENAARS AND HAMPDEM-TURNER 2012): individualism (individualistic $x$ collectivist), action (doing $x$ being), communication (high-context and low-context), thinking (inductive-linear $x$ deductive-systemic). It is important to emphasize that the opposing

TradTerm, São Paulo, v.37, n. 2, janeiro/2021, p. 644-670 Número Especial - Linguística de Corpus www.revistas.usp.br/tradterm 
orientations within each dimension operate on a continuum and not on disconnected axes. This is to say that cultures are not believed to be found exclusively in one of the poles; rather each culture features all the existing categories, but some of them tend to be more valued and stand out along this continuum of possibilities, according to specific situations or social groups. In this respect, Trompenaars and Hampdem-Turner (2012: 37) argue: “As opposed to running the risk of getting stuck by perceiving cultures as static points on a dual-axis map, we believe that cultures dance from one preferred end to the opposite and back."

\section{Data and methodology: a CL approach}

In order to investigate the ways in which cultural orientations influence collocational meaning, this paper draws on the theoretical and methodological principles of CL. Researches in CL are concerned with the observation of language patterns attested through authentic instances of language extracted from a corpus (MCENERY AND WILSON 2001). This approach constitutes a perspective of language as a probabilistic and standardized system (TOGNINI-BONELLI 2001), which means that lexical choices and combinations do not occur randomly, but constitute single choices from semipreconstructed phrases that are available to language users (SINCLAIR 1991: 109). Therefore, the primary unit of meaning goes beyond that of single words to encompass multiword patterns. Tognini-Bonelli (2002) applies this notion of meaning to the study of equivalence across languages. In order to reach equivalence, the first step is to 1 ) identify functionally complete units of meaning (node word and collocates) in the source language; then 2) find a collocational pattern that conveys the same or closest meaning in the target language. This study applies this methodology and takes it one step further in an attempt to 3 ) identify collocational patterns that are equivalent not only at the linguistic and pragmatic levels, but that also match in terms of underlying associations or cultural orientations (MANCA 2012).

TradTerm, São Paulo, v.37, n. 2, janeiro/2021, p. 644-670

Número Especial - Linguística de Corpus www.revistas.usp.br/tradterm 
This study explores a corpus of travelers' reviews extracted from the website TripAdvisor ${ }^{1}$. Travelers' reviews consist basically of an evaluation voluntarily written by consumers on a given tourism product, in our case, hotel stays. This text type was chosen based on the assumption that when people write a hotel review, they are expressing more than a mere evaluation of or opinion on a hotel stay. They are in fact describing a personal experience and thereby sharing their perceptions, thoughts, ideas, expectations, attitudes, frustrations, feelings, emotions, values and beliefs, which ultimately reveal part of their identity and worldviews, in other words, aspects of their culture. In this sense, Hall argues (1977: 16):

Culture is man's medium; there is not one aspect of human life that is not touched and altered by culture. This means personality, how people express themselves (including shows of emotion), the way they think, how they move, how problems are solved (...). However (...) it is frequently the most obvious and taken-for-granted and therefore the least studied aspects of culture that influence behavior in the deepest and most subtle ways.

Our study corpus is comprised of 15,000 hotel reviews: 7,500 written in English by American ${ }^{2}$ travelers and 7,500 written in Portuguese by Brazilian ${ }^{3}$ travelers. It contains a total of 2,160,333 words: 1,383,188 in English and 777,145 in Portuguese. This content is further divided into two subcorpora in each language: American reviews of hotels in the USA [AmeUSA] and hotels in Brazil [AmeBRA]; Brazilian reviews of hotels in the USA [BraUSA] and hotels in Brazil [BraBRA]. In more detail, each of the four subcorpora includes a similar number of different types of reviews according to traveler rating (excellent, very good, average, poor, terrible) and traveler type (families, couples, business).

This corpus was explored using linguistic analysis software WordSmith Tools 7 (SCOTT 2016) and its main tools: wordlists, keywords, lists of collocates, clusters and concordances.

\footnotetext{
1 https://www.tripadvisor.com/Tourism-g191-United_States-Vacations.html

${ }^{2}$ Reviews in English were extracted from TripAdvisor profiles of individuals whose place of origin was a city in the USA.

${ }^{3}$ Reviews in Portuguese were extracted from TripAdvisor profiles of individuals whose place of origin was a city in Brazil.
}

TradTerm, São Paulo, v.37, n. 2, janeiro/2021, p. 644-670 Número Especial - Linguística de Corpus www.revistas.usp.br/tradterm 
As a starting point for our corpus-driven analysis, we generated a list of keywords in each language to extract the statistically significant words from the corpus. We then classified those words into five semantic categories: physical attributes, amenities, stay, value/judgement and service. The "service" category was selected for the present study as it illustrates well the findings from our research as a whole (NAVARRO 2018). Furthermore service encounters in hotels entail some sort of human interaction; in the specific case under analysis, they take place between hotel providers and customers belonging to different cultural backgrounds, which affects their expectations and views with regards to quality service.

The analysis begins with the keyword staff and proceeds with its prima facie equivalent funcionários. It then moves on to the discussion of results and comparisons in terms of cultural orientations.

\section{Corpus analysis: staff}

Under the service category in English, we selected the most frequent keyword - staff - for analysis. It contains 5,186 occurrences, almost evenly distributed between the two English subcorpora, 2,750 hits in AmeBRA and 2,436 in AmeUSA. The following step was to generate a list of collocates in each subcorpus. The lists are summarized in Table $1^{4}$ to illustrate the main findings, organized by Z-score:

Table 1. Partial list of collocates of staff subcorpus.

\begin{tabular}{|c|c|c|c|}
\hline \multicolumn{2}{|c|}{ 'staff' (2.750) [AmeBRA] } & \multicolumn{2}{|c|}{ 'staff' (2.436) [AmeUSA] } \\
\hline \multicolumn{2}{|c|}{ Collocates } & \multicolumn{2}{|c|}{ Collocates } \\
\hline friendly (503) & polite (32) & friendly (493) & polite (28) \\
\hline helpful (410) & knowledgeable (19) & helpful (263) & courteous (30) \\
\hline English (207) & pleasant (47) & member (70) & trained (17) \\
\hline courteous (58) & eager (14) & attentive (54) & pleasant (42) \\
\hline desk (279) & efficient (27) & accommodating (52) & competent (7) \\
\hline front (245) & unfriendly (12) & rude $(62)$ & eager (12) \\
\hline attentive (65) & trained (13) & desk (202) & irritated (3) \\
\hline accommodating (59) & friendliness (6) & front (196) & unhelpful (10) \\
\hline speak (90) & cordial (6) & welcoming (31) & friendlier (5) \\
\hline professional (46) & welcoming (17) & professional (41) & personable (5) \\
\hline spoke $(74)$ & caring (7) & responsive (12) & friendliness (5) \\
\hline rude (48) & & cordial (10) & unfriendly (9) \\
\hline
\end{tabular}

${ }^{4}$ Partial list of collocates organized by $Z$ score. Minimal frequency of occurrence: 3 hits within a L5XR5 window (five words to the left and to the right of the node)

TradTerm, São Paulo, v.37, n. 2, janeiro/2021, p. 644-670 Número Especial - Linguística de Corpus www.revistas.usp.br/tradterm 
Initially, collocates in Table 1 are significant in three different ways: a) the most frequent adjectives are by far friendly and helpful on both subcorpora; b) there is a high incidence of negative and positive lexical items, mainly adjectives, on both lists; c) the word English is the third most recurrent collocate in the subcorpus AmeBRA. These initial observations will be looked at in further details and compared with the Portuguese data.

Considering the entire English corpus, staff co-occurs 996 times with friendly and 673 times with helpful. Further the cluster friendly and helpful occurs 231 times while helpful and friendly, in reverse order, appears 58 times. Hence it can be said that friendly and helpful staff makes up a significant collocation in English reviews. This points to two characteristics that are highly valued in the American reviews when it comes to staff service: one the one hand, interpersonal care - friendly, kind, cordial, welcoming, etc.; on the other hand, professional competence - helpful, efficient, competent, knowledgeable, etc. Let's look at two examples that illustrate this argument:

"Truly a gem, incredible service and very friendly staff" I just
completed my second business trip and stayed at the Gran
Estanplaza. Both times, the quality of the facilities and service,
and the friendliness of the staff have been consistently
excellent. (...) Their biggest assets are their consistently
friendly, helpful and english-speaking staff. I was recognized by
name every time after checkin, and everything I needed was
dealt with quickly. [AmeBRA_EXBUS91]

"Friendly Helpful Staff" I gave this hotel 4 stars for its helpful and friendly staff and good choices of breakfast. The reception is very friendly and helpful, especially the manager, Fernando, who speaks excellent English, shows us where to go and how to get there. They are trying very hard to accomodate our needs. (...) [AmeBRA_VGFAM157]

The reviews above illustrate the importance travelers place on friendliness and helpfulness factors as well as how they tend to be specific about these aspects: "I was recognized by the name" (friendly), "everything I needed was dealt with quickly" (helpful), "shows us where to go and how to get there" (helpful). Similarly, staff's failure to meet these expectations is a reason for complaint and frustration, as evidenced by negative collocates such

TradTerm, São Paulo, v.37, n. 2, janeiro/2021, p. 644-670 Número Especial - Linguística de Corpus www.revistas.usp.br/tradterm 
as unfriendly and unhelpful in Table 1. The next example shows once again the tendency to be specific about the failures: "the desk staff gave us misinfornation about laundries (...)" (unhelpful); "No one ever smiled" (unfriendly).

"Most incompetent, unhelpful, unfriendly front desk staff ever!" Good location, clean rooms. The incredibly incompetent front desk staff was matched by the equally incompetent reservation office (...). During our stay, the desk staff gave us misinfornation about laundries, internet and bus stops. They refused to make dinner reservations or to confirm our flights. No one ever smiled. [AmeBRA_POFAM109]

Therefore we notice the existence of two distinct semantic fields we shall refer to as "personal care" and "professionalism", which can be observed on positive and negative ways. The following reviews, for example, clearly show this distinction as one of the aspects receives positive evaluation and the other negative criticism.

Reception desk staff are not that friendly but perform their job well (...) [AmeBRA_AVEFAM37]

There are 10-15 rooms maximum and the staff although very nice and courteous but seemed unorganized and always depend on the owners whom are only there in the morning (...) [AmeBRA_POFAM93]

With this focus in mind, the collocates of staff, mostly adjectives, were classified according to the semantic associations under "personal care" or “professionalism”. The results are in Table 2 below.

Table 2: Collocates of 'staff' classified by semantic field.

\begin{tabular}{|c|c|c|}
\hline \multirow{2}{*}{ Positive prosody } & \multicolumn{2}{|c|}{ 'staff' (5.186) [AmeBRA_USA] } \\
\cline { 2 - 3 } & Personal care & Professionalism \\
& friendly (996) & helpful (673) \\
& courteous (88) & attentive (119) \\
& polite (60) & accommodating (11) \\
pleasant (89) & professional (74) \\
& welcoming (48) & knowledgeable (32) \\
& kind (46) & rempetent (11) \\
& warm (30) & trained (30) \\
& cheerful (11) & efficient (43) \\
& personable (10) & informative (5) \\
& cordial (14) & prompt (9) \\
& caring (9) & eager (26) \\
& gracious (12) & willing (19) \\
& hospitable (6) & bilingual (5) \\
\hline
\end{tabular}

TradTerm, São Paulo, v.37, n. 2, janeiro/2021, p. 644-670 Número Especial - Linguística de Corpus www.revistas.usp.br/tradterm 


\begin{tabular}{|c|c|c|}
\hline & smiling (9) & fluent (7) \\
& friendlier (8) & multilingual (3) \\
& friendliest (6) & apologetic (6) \\
& thoughtful (3) & professionalism (6) \\
& friendliness (11) & \\
\hline hospitality (9) & 1087 \\
\hline Entries & $\mathbf{1 4 6 8}$ & unhelpful (18) \\
prosody & rude (110) & incompetent (9) \\
& unfriendly (21) & clueless (5) \\
& indifferent (15) & unprofessional (8) \\
& arrogant (7) & unresponsive (9) \\
& listless (5) & unmotivated (3) \\
& impersonal (4) & apathetic (3) \\
& uncaring (3) & disorganized (4) \\
& unpleasant (4) & inexperienced (4) \\
& inattentive (8) \\
& apinterested (3) & unapologetic (3) \\
\hline Entries & rudest (3) & \\
\hline
\end{tabular}

It is important to add that the words in Table 2 are not used exclusively in positive or negative ways. The analysis of concordance lines shows several instances of not friendly, should be more polite, was never courteous and so on. Our point is to show that friendly and helpful staff constitutes not only a highly conventionalized collocation but also acts pervasively as an "umbrella collocation", representing distinctive and standardized semantic fields made up of several different words. The excerpts below illustrate this argument further.

(...) The staff is wonderful, polite and professional. [AmeBRA_AVEBUS74]

(...) First, the staff is extremely helpful and approachable. [AmeBRA_EXCOU05]

(...) With the exception of the bar staff, the rest of the hotel staff was rude, unresponsive, and unprofessional. [AmeBRA_POFRI14]

(...) I have stayed twice and the staff have always been very helpful and pleasant. [AmeBRA_VGBUS110]

Moreover it is relevant to notice that there is a slight higher number of collocates related to personal care $(1,650)$ as to professionalism $(1,161)$. The same difference was found when comparing the number of occurrences within each semantic field between AmeUSA and AmeBRA subcorpora, in other words, the greater emphasis on elements of personal care remains the same regardless of the context of travel, whether in Brazil or in the USA.

TradTerm, São Paulo, v.37, n. 2, janeiro/2021, p. 644-670 Número Especial - Linguística de Corpus www.revistas.usp.br/tradterm 
As we have seen, American reviews tend to show a high level of specificity to evaluate staff service. One way American reviewers consider the service specifically helpful is judged by the ability of staff members to speak English and provide information. This is evidenced by collocates such as English, speak, speaks, spoke (Table 1). The analysis of the word English showed 795 hits of the word, mostly in the AmeBRA subcorpus, i.e. the service in English is clearly a concern when Americans are traveling abroad. A thorough analysis of concordance lines confirmed Americans' high level of expectation and value for service in their native language, which is directly linked to the staff's professional skills (helpfulness), as Figure 1 and the following reviews demonstrate.

Figure 1. Partial concordances for English and its association with helpful [AmeBRA].

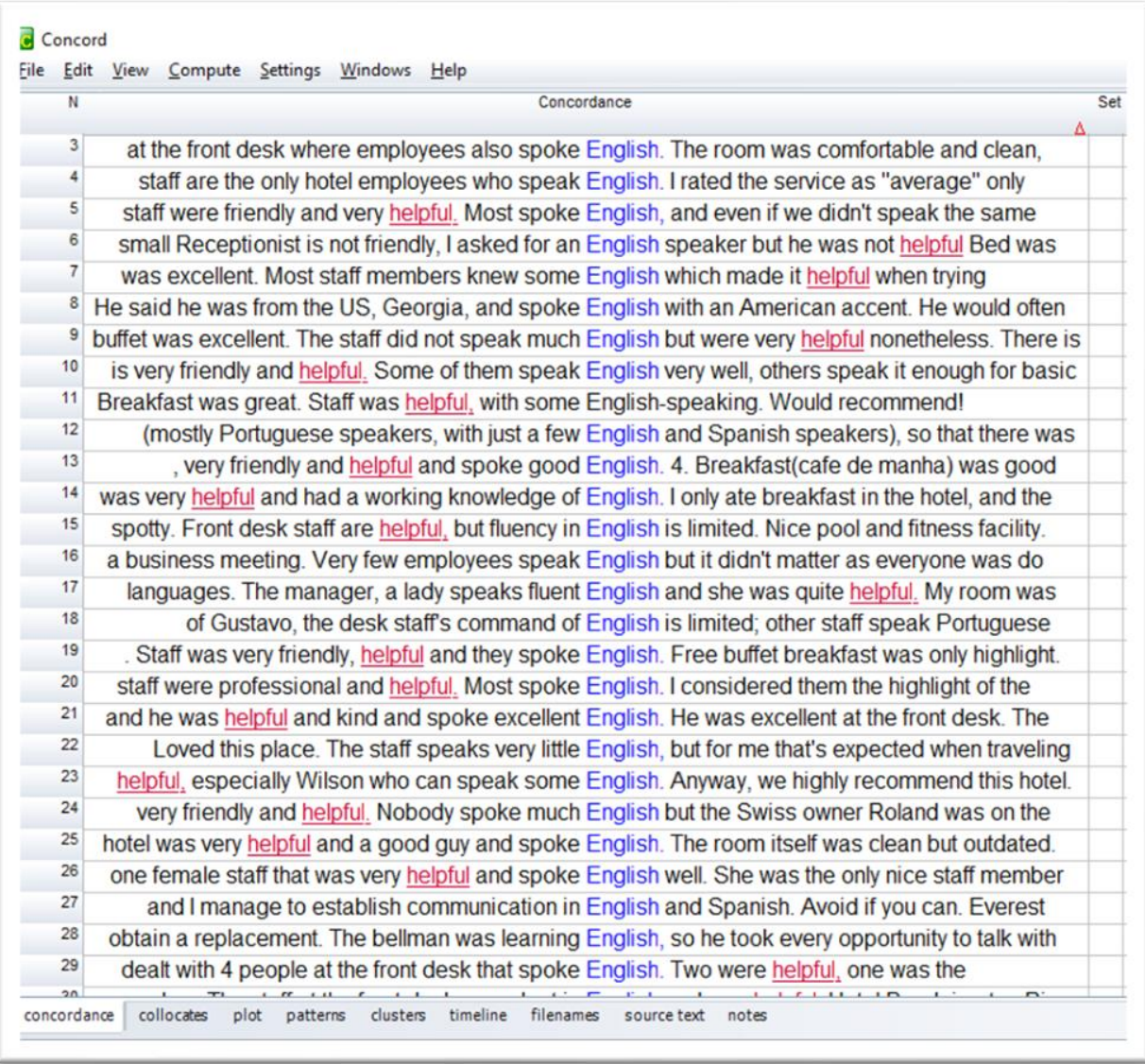

The overall service we experience from the staff was super! No worries, if your Portuguese needs improvement, because the front desk was staffed 24/7 with a super friendly, very professional, English speaking staff member. [AmeBRA_EXBUS117]

TradTerm, São Paulo, v.37, n. 2, janeiro/2021, p. 644-670 Número Especial - Linguística de Corpus www.revistas.usp.br/tradterm 
I traveled all over the world, and I know that at least people working in a hotel should speak some English. I speak Spanish, English and French, so I was able to comunicate somehow with the staff at this hotel. They didn't even make the effort to understand my questions. They didn't have maps, they didn't know how to get any where. The staff was not helpful at all. The hotel is ok, but when you are a tourist you need to have some guiadance from the hotel before you get to know the city a bit. (...) [AmeBRA_POCOU39]

The next section presents the analysis of staff's prima facie equivalent in Portuguese, funcionários. The first parallels with the English findings shall be drawn.

\section{Corpus analysis: funcionários}

The word funcionários was selected for analysis for being the most frequent prima facie equivalent under the service category in Portuguese. It has 1,160 occurrences in the plural form and 232 in the singular form, totaling 1392 entries. It is a high frequency but considerably lower than its English counterpart with over 5,000 entries. Part of the reason for this difference is morphological: while staff makes up several compounds in English, such as parking staff, front desk staff, housekeeping staff, specific single terms are used in Portuguese, such as manobristas, recepcionistas, camareiros, respectively. Also Brazilians frequently evaluate service by using the more generic noun atendimento or the verb atender in sentences such as "o atendimento foi péssimo" or "fomos mal atendidos", without specific reference to funcionários. Still we opted to investigate funcionário(s) as it is the most frequent prima facie equivalent, it is a hyperonym for the different kinds of hotel employees and it allows for a focus on the human factor of service just like staff.

Following the same analysis procedure adopted in English, we generated a list of collocates for funcionário(s) in each subcorpus (BraUSA and BraBRA). The main findings are summarized in Table 3. 
Table 3. Partial list of collocates of funcionário(s) arranged by subcorpus (BraUSA / BraBRA).

\begin{tabular}{|ll|ll|}
\hline \multicolumn{2}{|c|}{ 'funcionário(s)' (541) [BraUSA] } & \multicolumn{2}{c|}{ 'funcionário(s)' (851) [BraBRA] } \\
\hline Collocates & \multicolumn{2}{c|}{ Collocates } \\
\hline atenciosos (97) & preparados (5) & atenciosos (130) & preparados (8) \\
prestativos (38) & solícitos (6) & educados (105) & cordialidade (8) \\
simpáticos (37) & atendido(s) (6) & pimpáticos (69) & eficientes (6) \\
educados (44) & português (3) & gentativos (45) & treinamento (6) \\
humorado(s) (8) & treinados (4) & solícitos (27) & antipáticos (4) \\
gentis (15) & cordialidade (4) & treinados (23) & simpátos (5) \\
cordiais (9) & tratamento (4) & cordiais (14) & educação (6) \\
grosseiros (6) & falam (3) & mal (44) & corteses (3) \\
corteses (4) & agradáveis (3) & humorados (11) & esforço (3) \\
grossos (4) & mal (20) & receptivos (5) & tratamento (5) \\
eficientes (3) & ajudar (5) & atendimento (78) & vontade (8) \\
despreparados (6) & atendimento (41) & despreparados (9) & simpatia (5) \\
simpatia (8) & vontade (10) & \multicolumn{2}{|c|}{} \\
\hline
\end{tabular}

The most frequent collocate on both lists is atenciosos, which can be translated as courteous, attentive or considerate ${ }^{6}$. Interestingly the definition of attentive in English includes the notion of helpful ${ }^{7}$. So even though atenciosos is closest in meaning to friendly, it encompasses part of the meaning of helpful. The next most frequent collocates vary slightly between the two subcorpora: prestativos, simpáticos, educados, gentis in BraUSA; educados, simpáticos, prestativos, gentis in BraBRA, all revolving around the meanings of friendly and helpful. The list of clusters shows a similar variation of patterns among these words; the most recurrent collocations identified considering the entire Portuguese corpus are: funcionários educados $e$ prestativos, with 15 entries, and funcionários atenciosos e prestativos, with 11 hits. These two collocations can be regarded as equivalent for friendly and helpful staff as they also represent the semantic fields of personal care and professionalism; however, the difference in the number of entries between Portuguese and English (15 or 11 vs. 231) is considerable, pointing to a stronger or more conventionalized collocation in English. Figure 2 shows partial concordances lines for funcionários (BraUSA), where it is possible no notice how funcionários atenciosos followed by connector $e$ does not make up recurrent collocations.

\footnotetext{
${ }^{5}$ Ordered by statistic measure Z-score.

${ }^{6} \mathrm{http}: / /$ www. portuguesedictionary.net/atencioso.htm

7 "If someone is attentive, they are very helpful and take care of you" https://dictionary.cambridge.org/dictionary/english/attentive

TradTerm, São Paulo, v.37, n. 2, janeiro/2021, p. 644-670

Número Especial - Linguística de Corpus www.revistas.usp.br/tradterm
} 
Figure 2. Partial concordances for funcionários aligned by collocates on the right (BraUSA).

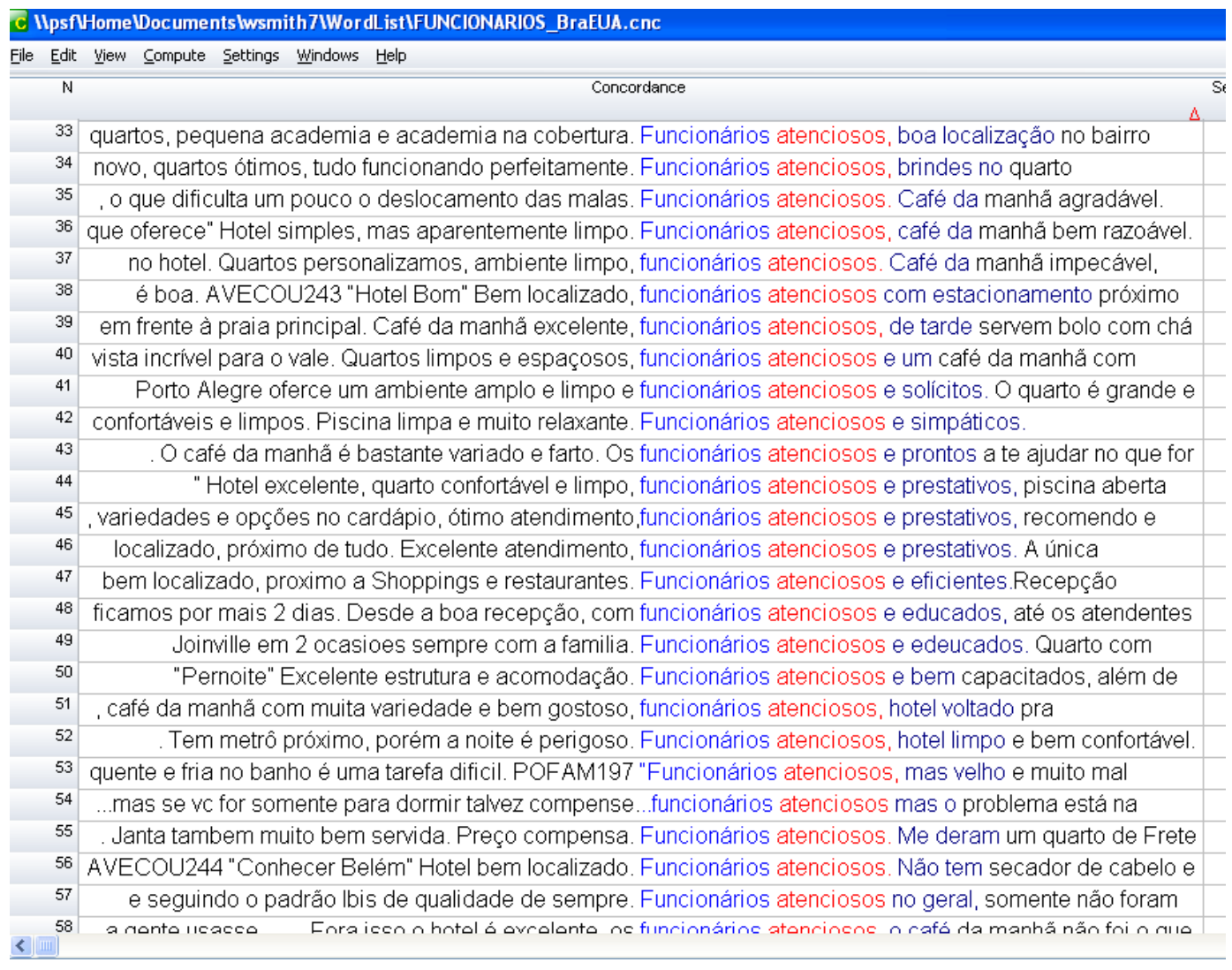

In order to further observe the semantic categories of personal care and professionalism in Portuguese, the next step was to classify all collocates of funcionário(s) according to these fields. The results are in Table 4.

TradTerm, São Paulo, v.37, n. 2, janeiro/2021, p. 644-670 Número Especial - Linguística de Corpus www.revistas.usp.br/tradterm 
Table 4. Collocates of funcionários classified by semantic field.

\begin{tabular}{|c|c|c|}
\hline \multirow{2}{*}{ Positive } & 'funcionário(s)' (1.162) [BraBRA_USA] \\
\cline { 2 - 3 } prosody & Personal care & Professionalism \\
& atenciosos (227) & prestativos (103) \\
& educados (149) & treinados (30) \\
& simpáticitos (38) \\
& gentis (46) & eficientes (11) \\
& competentes (3) \\
& coceptivos (23) (7) & preparados (11) \\
& dispostos (8) & presteza (6) \\
& corteses (7) & \\
& amigáveis (3) & \\
& cordialidade (12) & \\
& simpatia (13) & \\
\hline Entries & hospitalidade (3) & \\
\hline Negative & cortesia (8) & \\
prosody & gentileza (3) & \\
& grosseiros (8) & \\
& mal-humorados (17) & \\
\hline Entries & antipáticos (6) & \\
\hline
\end{tabular}

As seen in Table 4, several collocates of funcionário(s) belong to the semantic fields of personal care and professionalism, both with positive and negative prosodies. As in English, there is a greater focus on the elements of personal care. However the numbers suggest that this difference is deeper in Portuguese, as there are three times more collocates under personal care. Once again though, it is evident that these two categories are not as strongly represented in Portuguese as in English. Not only did we identify fewer words (for ex., only one collocate under professionalism/negative), but the overall number of entries is at least three times lower in Portuguese. For both languages we identified a greater number of collocates with positive prosody, however, this should be looked at carefully, as a closer look at concordance lines shows several examples of inverted polarity (falta de cordialidade, nada simpáticos, pouco atenciosos, simpatia zero). Still the main point is to demonstrate that the two sematic fields are observed on both languages, but they are less representative or less marked in Portuguese.

The fact identified above means that Brazilian reviews tend to differentiate or specify less the aspects that justify good or bad service evaluations. A detailed analysis of concordance lines and full reviews 
containing funcionários confirmed this tendency. The following review illustrates how a satisfied guest compliments the staff, mentioning how surprised he/she was by the service, but no specific information is given. In the second review, the guest describes a specific problem with the number of beds in the room, but then credits the staff's inability or unwillingness to solve the problem to their lack of courtesy or friendliness.

Estrutura excelente, funcionários EXTREMAMENTE gentis, prestativos e educados. A comida? Sensacional. (...). Todos os funcionários são o mais prestativos possíveis, o atendimento foi uma das coisas que mais me deixou surpreso (...). [BraUSA_EXCOU249]

Fiz uma reserva pelo Booking.com para um quarto quadruplo, com duas camas de casal e quando cheguei ao hotel nos colocaram num quarto com apenas uma cama de casal! Tentei resolver a situação, mas os funcionários, nada corteses, falaram que não teriam como solucionar a situação. E não demostraram o menor interesse em fazê-lo (...). [BraUSA_AVEFAM98]

As we have seen previously, Americans reviews link Brazilian hotel staff's ability to speak English to the level of professionalism. Table 3 shows the words português and falam among the collocates of funcionários. In order to compare American and Brazilian expectations in this regard, we investigated the uses of português in the BraUSA subcorpus.

The word português occurs 21 times in BraUSA, a surprisingly low number when compared to the 795 hits of English in AmeBRA. This fact alone suggests that Brazilian travelers do not often find or expect to find hotel staff who speaks Portuguese and/or that they do not see this as a relevant issue. A thorough analysis of all 21 concordance lines revealed only 11 cases when Brazilian travelers were treated in their native language. Further, no connections between staff language expertise and professionalism were found. The following example illustrates this finding. The Brazilian guest regards staff service as excellent, even though no one spoke Portuguese and he/she apparently does not speak another language; however, the issue is dismissed as unimportant: "nada demais".

TradTerm, São Paulo, v.37, n. 2, janeiro/2021, p. 644-670

Número Especial - Linguística de Corpus www.revistas.usp.br/tradterm 
Me hospedei quando ainda se chamava Quality inn, o que mais chamou a atenção foi o excelente atendimento. Para quem precisa sabe, o hotel, pelo menos em minha estadia não dispunha de atendente que fale português, nada demais (...). [BraUSA_AVEBUS134]

The relationship between the findings above and cultural orientations shall be addressed in the following section.

\section{Discussions of results: cultural orientations}

The corpus analysis in English identified friendly and helpful staff as a recurrent collocation which is conventionalized to the point of representing two semantic fields we named "personal care" and "professionalism". In Portuguese, we identified two possible equivalent collocations, funcionários educados e prestativos and funcionários atenciosos e prestativos as well as the same semantic fields made up of other related collocates. Nonetheless, we could attest a major difference between the two languages: the collocation was more frequent, thus more conventionalized and cohesive, and the semantic fields more representative and marked in English than in Portuguese. This difference was clear from the fact that one very recurrent collocation in English had two equivalents in Portuguese, both with very few occurrences, and both semantic fields in English were made up of more collocates. This pointed to differing tendencies between Americans and Brazilians regarding the level of specificity about staff service evaluation.

This difference in language use is influenced by distinct dominant cultural orientations between Brazilians and Americans. We start by describing it in terms of individualistic-collectivist orientations as well as doing-being orientations (WALKER et al. 2003).

The individualism dimension refers to the way social identity is defined. In this sense, cultures differ in their valuing of and perspective on identity based on group affiliation (collectivist) or individual achievement (individualistic) (WALKER et al. 2003: 77). One way in which individualistic and collectivist societies differ concerns how status is assigned to its members (TROMPENAARS AND HAMPDEN-TURNER 2012). Individualistic cultures accord status to people on the basis of their individual's actions, i.e. personal efforts that

TradTerm, São Paulo, v.37, n. 2, janeiro/2021, p. 644-670 Número Especial - Linguística de Corpus www.revistas.usp.br/tradterm 
result from accomplishing goals, completing tasks, getting things done, hence they display a doing orientation. Consequently in individualistic-doing environments there is a clearer differentiation between the individual and his/her actions (you are and you do). Conversely, collectivist societies confer status by virtue of factors external to the individual's direct control, such as affiliation, group membership, social class and personal connections (WALKER et al. 2003: 67). They place high value on relationships, which ascribes them a being orientation. Collectivist-being cultures find it more difficult to isolate the individual's actions from the individual itself (you are what you do).

The study of staff confirmed the dominant American individualisticdoing orientations and Brazilian collectivist-being orientations found in the literature (WALKER et al. 2003, HOFSTEDE 2001). This explains the American tendency to distinguish more clearly between factors related to staff's interpersonal abilities from professional competence. In other words, Americans tended to isolate personal traits from concrete actions, which can be closely associated with the semantic fields of friendly and helpful. Brazilians' collectivist-being orientation accounts for the tendency to be more generic or differentiate less between staff's concrete actions and personal traits, sometimes even blending both.

Given the doing $x$ being orientation divide, one would expect American reviews to place heavier emphasis on task-related aspects (helpfulness) and Brazilian reviews on relationship-related qualities (friendliness). However our data suggest that both cultures place more emphasis on friendliness, when comparing the number of collocates under each semantic category. What differs though is the greater degree to which Americans stress, distinguish and specify the professional aspect, both in positive and negative ways.

The following reviews illustrate these arguments. The first one shows an American reviewer's harsh criticism of the staff performance, but before doing so, the person recognizes the staff's friendliness - "while pleasant, they..." - and then goes on to list a number of concrete facts. The next is a Brazilian guest who begins the review by describing a problem with the booking. Despite the fact that his/her problem was solved, the guest resents not having been treated well. The focus is on a general "feeling" of

TradTerm, São Paulo, v.37, n. 2, janeiro/2021, p. 644-670 Número Especial - Linguística de Corpus www.revistas.usp.br/tradterm 
dissatisfaction and there is little distinction between interpersonal skills and professional expertise.

\begin{abstract}
"Staff need training on excellent service standards" (...) The most disappointing however was the staff. While pleasant they just seemed like amateurs pretending to know how a "5 star" hotel should be operated. No one addressed you by name, they rarely even spoke, the "butler" never showed his or her face, the turn down service was hit or miss, housekeeping was sporadic, not one platinum amenity was offered, concierge had little knowledge of ethnic food options. (...) [AmeUSA_AVEBUS180]

(...) Nossa surpresa foi ao chegar lá que nos acomodaram em um quarto de categoria inferior o que havíamos reservado. (...) Depois de ser mal tratado por 3 atendentes da recepção, insistimos $e$ conseguimos falar com o gerente, que, apenas para se livrar do problema nos deu um upgrade de categoria. A cordialidade dos funcionários é o fato que mais me chamou a atenção. Os funcionários devem ser treinados para maltratar os turistas... desde o mensageiro ate o gerente, não fomos bem recebidos por nenhum deles. [BraEUA_TERCOU224]
\end{abstract}

The tendencies to specificity or generalization discussed above are also linked to the cultural orientations toward communication and thinking.

Hall (1977) introduces the distinction between low-context culture and high-context culture communications, which are dominant in American and Brazilian cultures respectively (KATAN 2004: 253). These orientations relate to the differing amount of context and text that tends to be shared implicitly or explicitly during communication. Context means "stored information" and is related to the notion of "context of situation and wider context of culture" (KATAN 2004: 240) or a "shared and implicit framework of interpretation to a message" (WALKER et al. 2003: 66), while text is the transmitted information. In this sense, low-context communication has a preference for text, which implies that the mass of information is made explicit in the linguistic code. The result is specificity and direct style, focus on facts, concrete data, detailed information, accuracy. This orientation reveals an inductive and linear thinking orientation, which values data analysis, empirical observation, precision, cause and effect logic (WALKER et al. 2003: 84-85). By contrast, high-context communication relies more on the context shared by

TradTerm, São Paulo, v.37, n. 2, janeiro/2021, p. 644-670 Número Especial - Linguística de Corpus www. revistas.usp.br/tradterm 
participants, which implies that a great deal of text is implicit during communication. This entails low information density, general descriptions, omissions, indirect and expressive style. This orientation is linked to a deductive and systemic mode of thinking, which places greater emphasis on the conceptual world rather than the amassing of facts and prioritize an integrated approach to problem-solving. There is frequent use of metaphor, simile and analogy for explanations (WALKER et al. 2003: 84).

The previous analysis of friendly and helpful staff provides ample evidence of the influence of American low-context and Brazilian high-context communication orientations, starting from the difference in number of occurrences between staff $(5,186)$ and funcionários $(1,160)$. Added to that is our analysis of the words English and português. As we have seen, Americans referred to their native language 795 times (AmeBRA). The word English was frequently associated to the co-text of helpful and was used in an attempt to specify a concrete fact related to staff's performance: the ability to provide information. Português, on the other hand, was mentioned 21 times only (BraUSA). None of the entries were explicitly linked to the staff's professional skills. It is logical to assert that, because Brazilians do not usually expect to find Portuguese-speaking hotel staff when traveling abroad, this information is implicit in Brazilians' context of communication, it goes without saying, and making it explicit is not necessary. As we have attempted to illustrate, the focus of the Brazilian reviews with regard to hotel staff was less on details, facts and precision and more on general impressions or feelings of (dis)satisfaction.

The following reviews are good examples of the low and high orientations to communication.

"The staff members were not professional and not very helpful" (...) Our enthusiasm about the Hotel was dampened because of many bad interactions (communications) with the staff members in the front desk and their un-helpfulness. If you cannot speak Portuguese or you speak English, please don't expect to get any help from the staff and you will not get the same service as the three to five stars hotels in America. It is very difficult to get very simple information from the staff members; they are not very helpful. The staff members do not have a broad knowledge about the City and surrounding. (...) The Hotel travel agent was

TradTerm, São Paulo, v.37, n. 2, janeiro/2021, p. 644-670 Número Especial - Linguística de Corpus www.revistas.usp.br/tradterm 
not very helpful either; the travel agent is set up not to give you any help but it is set up for you to spend more money without good services (...). The Hotel needs to send their staff members for training to Tourism schools outside Brazil if the Hotel wants to improve their service for customers from outside Brazil. It is ashamed that a very nice Hotel has mediocre services from the staff with low communication and interpersonal skills. [AmeBRA_AVECOU221]

0 ponto forte deste hotel é a sua localização. (...). 0 ponto negativo é o atendimento, a impressão que tive é que os funcionários foram treinados para serem rudes, não tem um mínimo de simpatia da maioria deles, tem momentos que você se sente um intruso e não um hóspede. [BraUSA_AVEFAM40]

In the first review an American states clearly the expectation (context) regarding hotel staff's ability to help or, more specifically, to provide guests with information in English. There is an explicit association of concrete facts and the disappointment with the service - "It is very difficult to get very simple information...". We can argue that the fact that an American cannot obtain relevant information in English goes against their individualistic orientation, which values autonomy, independence, getting things done. As a further reflection of doing and low context orientations, the guest concludes by exhorting the hotel to take concrete actions to improve their service. By contrast, the Brazilian review stresses personal impressions - " $a$ impressão que tive..."; it gives no concrete information to justify staff's unfriendliness; it makes use of generalization - "a maioria deles"; and the traveler concludes by stressing how the service made him/her feel - "você se sente um intruso". It is interesting to compare the literal use of the word trained in low-context communication - "send staff members for training" -, and the metaphorical or expressive meaning of treinados typical of high-context communication "foram treinados para serem rudes".

\section{Conclusions}

This essay has attempted to demonstrate that a deeper understanding of cultural orientations plays a role in the identification of collocational meaning and equivalence across languages. The most recurrent collocates of

TradTerm, São Paulo, v.37, n. 2, janeiro/2021, p. 644-670 Número Especial - Linguística de Corpus www.revistas.usp.br/tradterm 
staff - friendly and helpful - reveal not only two attributes highly valued by American travelers when evaluating service, but they also reflect a tendency to distinguish more clearly between professional and interpersonal aspects, i.e., the individual's concrete actions and the individual itself. This could be interpreted as a reflection of American culture's dominant orientations to individualism, doing, low context communication and inductive-linear thinking. This finding has shown that culture operates in unconscious and subjective ways, affecting people's perceptions of reality and consequently their language use. Hence it is possible to assert that friendly and helpful staff represents at once a language pattern and a cultural pattern.

In search for an equivalent in Portuguese, we identified funcionários atenciosos e prestativos and funcionários educados e prestativos. We can argue that these collocations are linguistically and pragmatically equivalent to their English counterpart, even though they are not a full match in terms of underlying cultural associations. As the findings have shown, the significant difference in frequency of use between English and Portuguese is due to the influence of distinct orientations, i.e. collectivist, being, high communication and deductive-systemic thinking, which are mostly predominant in Brazilian culture.

Throughout this essay, repeated references to "Brazilian" and "American" cultures have been made. It is important to recognize though that these cultures are not considered homogeneous entities, especially in the case of two countries of continental extensions and home to vast regional and socioeconomic diversity, such as Brazil and the United States. We are also aware of the risks involved in delineating cultures perfectly within national borders in a world constantly influenced by globalization and people flows (HANNERZ 1996). On the other extreme, these factors should not be considered capable of erasing all traces of national cultural identity. In this regard, HOFSTEDE (2001) shows that intra-national differences tend to be weaker than cross-cultural differences. In this research, we address this issue by looking at our data source and research findings. Our study corpus of TripAdvisor reviews is comprised of a total of 15,000 reviews or "individuals" from various parts of Brazil and the United States, encompassing different ages, TradTerm, São Paulo, v.37, n. 2, janeiro/2021, p. 644-670 Número Especial - Linguística de Corpus www.revistas.usp.br/tradterm 
professions, socioeconomic classes and ethnic groups. Therefore we can argue that the fuzzy boundaries and complexity of culture are, to a good extent, represented in our sample, which allows, not without limitations, our considerations about cultural differences in terms of nationalities. Furthermore, our corpus analysis of more than 2 million words enabled us to identify consistent patterns of language which reflect differing underlying cultural behaviors and values within the particular context of travelers' reviews.

As we have seen, the uses of one collocation and its equivalents could be interpreted within the framework of four different cultural dimensions individualism, action, communication and thinking. This fact points to the dynamic nature of cultural orientations which do not occur in isolation, but in integrated and comprehensive ways. It also suggests the challenge of adopting fixed categorizations for a complex and widespread phenomenon such as culture, therefore some degree of overlapping among orientations is expected. Despite this challenge, the model of cultural orientations applied together with a systematic corpus analysis have helped uncover facts about language use that would otherwise go unnoticed.

Our discussions should make an important contribution to the field of Translation Studies in general and to tourism translation in particular. Translation Studies should benefit from the insights of an empirical analysis of cultural differences which play a crucial role in pragmatic and cultural equivalence. Tourism translation and promotion may apply our findings to adopt functional communication strategies tailored to the specific target audience cultural orientations (see NAVARRO 2018).

As a final remark, we recall the epigraph that opens this essay hoping to have demonstrated the potential of Corpus Linguistics studies to reveal those hidden aspects that culture strangely hides even from its own participants (HALL [1959] 1990). 


\section{References}

BASSNETT-MCGUIRE S. Translation Studies. London: Methuen, 1980.

BIANCHI, F. Culture, Corpora and Semantics. Methodological Issues in Using Elicited and Corpus Data for Cultural Comparison. Lecce: Università del Salento, 2012.

FIRTH J.R. Papers in Linguistics. London: Oxford University Press, 1957.

GLADSTONE, J.R. Language and Culture in English teaching. London: Routledge and Kegan Paul, 1969.

HALL, E. T. The Silent Language. New York: Anchor Books, 1990 [1959].

HaLL, E. T. Beyond culture. New York: Anchor Press/Doubleday, 1977.

HallidaY, M. A. K. An Introduction to Functional Grammar. London: Arnold, 1985.

HANNERZ, U. Cultural complexity: studies in the social organization of meaning. New York: Columbia University Press, 1992.

HOFSTEDE, G. Culture's Consequences: Comparing Values, Behaviours, Institutions, and Organizations across Nations. 2 ed. Thousand Oaks (CA): Sage Publications, isepi2001.

InKELES, A.; LeVINSON, D. J. National Character: the Study of Model Personality and Sociocultural Systems. In: LINDSEY, G.; ARONSON, E. (eds). The Handbook of Social Psychology. 2nd ed. Vol. 4. Reading (MA): AddisonWesley, 1969.

KatAN, D. Translating Cultures. An Introduction for Translators, Interpreters and Mediators. Manchester: St. Jerome, 2004.

KLUCKHOHN, F. R.; STRODTBECK, F. L. Variations in Value Orientations. Evanston (IL): Row Peterson, 1961.

MaLINowsKI, B. The Problem of Meaning in Primitive Languages. In: OGden, C. K.; RICHARDS, I. A. (eds). The Meaning of Meaning: a Study of the Influence of Language upon Tought and of the Science of Symbolism. New York: Harcourt Brace and Co, 1938 [1923]: 296-336.

MANCA, E. Translating the language of tourism across cultures: from functionally complete units of meaning to cultural equivalence. In: Fodde, L.; Van Den Abeele, G. (eds). Textus. Tourism and Tourists in Language and Linguistics. Roma: Carocci editore, 2012.

MCEnerY, T.; WILSON, A. Corpus Linguistics. 2nd Edition. Edinburgh: Edinburgh University Press, 2001.

TradTerm, São Paulo, v.37, n. 2, janeiro/2021, p. 644-670 Número Especial - Linguística de Corpus www.revistas.usp.br/tradterm 
MUNTZ, R. Evidence of Australian cultural identity through the analysis of Australian and British corpora. In: Rayson P.; Wilson A.; McEnery T.; Hardie A.; Khoja S. (Eds). Proceedings of the Corpus Linguistics 2001 Conference. Lancaster University. 2001: 393-399.

NAVARRO FUCHS, S. Cultural orientations and functionalist translation: a corpusdriven study in tourism. 350 pages. Dissertation $(\mathrm{PhD})$ - Faculty of Philosophy, Languages and Literature, and Human Sciences, University of São Paulo, São Paulo, 2018. [Available in Portuguese at: https: / / teses.usp.br/teses/disponiveis/8/8160/tde-27082018$165601 /$ fr.php]

SAPIR, E. Culture, Language and Personality. Los Angeles: University of California, 1949.

SCHMID, H. J. Do women and men really live in different cultures? Evidence from the BNC. In: WILSON, A.; RAYSON, P.; MCENERY, T. (eds.), Corpora by the Lune. A festschrift for Geoffrey Leech. Frankfurt: Peter Lang, 2003: 185-221.

ScotT, M. WordSmith Tools. Version 7, Stroud: Lexical Analysis Software, 2016.

SINCLAIR, J. The Search for Units of Meaning. TEXTUS IX (1). Genova: Tilgher, 1996: 71-106.

SInCLAIR, J. Corpus, Concordance, Collocation. Oxford: Oxford University Press, 1991.

Snell-HoRnBy, M. Translation studies. Amsterdam; Philadelphia: John Benjamins, 1995.

Stewart, E.; Bennet, M. American Cultural Patterns: A Cross-Cultural Perspective, rev. ed. Yarmouth, Me: Intercultural Press, 1991.

TogninI-BonelLI, E. Corpus at Work. Amsterdam Philadelphia: John Benjamins, 2001.

TrompenAARS, F.; HAMPDEN-TURNER, C. Riding the Waves of Culture: Understanding Cultural Diversity in Business. 2nd ed. London: Nicholas Brealey Publishing, 2012.

WALKER, D.; WALKER, T.; SChMITZ, J. Doing Business Internationally: The Guide to Cross Cultural Success. USA: McGraw-Hill, 2003.

WHORF, B. L. Language, thought and reality. Selected writings, ed. J.B. Carroll. Cambridge: MIT Press, 1973.

Recebido em: 30/04/2020

Aceito em: 08/09/2020

Publicado em janeiro de 2021

TradTerm, São Paulo, v.37, n. 2, janeiro/2021, p. 644-670

Número Especial - Linguística de Corpus www.revistas.usp.br/tradterm 